\title{
Characterization of a new plasma membrane-associated ecto-5'-phosphodiesterase/nucleotide-pyrophosphatase from rat hepatocarcinoma AS-30D cells
}

\author{
R. M. García-Nieto, E. San José, J. Martín-Nieto* and A. Villalobo \\ Instituto de Investigaciones Biomédicas, Consejo Superior de Investigaciones \\ Científicas and Universidad Autónoma de Madrid, 28029 Madrid, Spain
}

(Received on May 19, 2000)

\begin{abstract}
R. M. GARCÍA-NIETO, E. SAN JOSÉ, J. MARTÍN-NIETO and A. VILLALOBO. Characterization of a new plasma membrane-associated ecto-5'-phosphodiesterase/nucleotide-pyrophosphatase from rat hepatocarcinoma AS-30D cells. J. Physiol. Biochem., 57 (1), 31-40, 2001.

We have identified in plasma membrane fractions isolated from rat hepatocarcinoma AS-30D ascites cells three glycoproteins of $125 \mathrm{kDa}, 115 \mathrm{kDa}$ and $105 \mathrm{kDa}$ (gp125, gp115 and gp105) which become adenylylated using ATP as substrate, most readily in the presence of EDTA. The gp115 becomes also phosphorylated. The adenylylation of these tumor glycoproteins was much lower than that of a group of analogous adenylylatable glycoproteins (gp130, gp120-gp110 dimer and gp100) present in normal rat liver plasma membrane. The tumor glycoproteins were reversibly $\mathrm{O}$-adenylylated at threonine residues, as was the case for their normal rat liver counterparts. The tumor gp115, and the gp120-gp110 dimer from normal rat liver were both isolated using either ATP-affinity chromatography and/or AMP-affinity chromatography. The gp120-gp110 dimer from normal rat liver was identified as the plasma cell differentiation antigen-1 (PC-1 protein), an ecto-5' phosphodiesterase/ nucleotide-pyrophosphatase (5'-PDE/NPPase). The gp115 from tumor cells also exhibited $\mathrm{Zn}^{2+}$-stimulated $5^{\prime}-\mathrm{PDE}$ and NPPase activities in alkaline conditions, although it appears to be distinct from the PC-1 protein. We have determined that the gp115 is an ecto-enzyme that catalyzes the hydrolysis of extracellular ATP, since its adenylylation and phosphorylation were detected in intact cells using extracellularly added $\left[\alpha_{-}{ }^{32} \mathrm{P}\right] \mathrm{ATP}$ or $\left[\gamma_{-}{ }^{32} \mathrm{P}\right] \mathrm{ATP}$, respectively, in the absence of any permeabilizing agent.
\end{abstract}

Key words: Adenylylation, AS-30D tumor cells, Ecto-5'-phosphodiesterase/nucleotidepyrophosphatase, Hepatocarcinoma.

* Present adress: División de Genética, Departamento de Fisiología, Genética y Microbiología, Universidad de Alicante, Spain.

Correspondence to: A. Villalobo (Fax: +34-91-585-4587; e-mail: antonio.villalobo@iib.uam.es). 
In previous studies, we reported the presence of a set of glycoproteins (gp130, gp120-gp110 dimer, gp100 and gp86) in the plasma membrane of normal rat liver which became labeled in the presence of $\left[\alpha_{-}{ }^{32} \mathrm{P}\right]$ ATP $(6,28-30)$. We demonstrated that the gp86 was a phosphodiesterase forming an adenylylated catalytic intermediate, although it was uncertain at that time whether the labeled gp130, gp120gp110 dimer and gp100 were also adenylylated intermediates of typical phosphodiesterases. This uncertainty was due to the low rate of turnover observed upon chase of the bound [ $\left.{ }^{32} \mathrm{P}\right] \mathrm{AMP}$ by an excess of non-labeled ATP (28). On the other hand, in the cell plasma membrane of the rat hepatocarcinoma AS-30D we detected the presence of three adenylylatable proteins of slightly different molecular masses than their normal rat liver counterparts (6). However, the nature and physiological functions of these proteins remained elusive.

It is well known that 5'-phosphodiesterases form adenylylated catalytic intermediates $(17,27,28)$. Moreover, a 130 $\mathrm{kDa}$ glycoprotein from bovine liver plasma membrane $(21,22)$ that becomes adenylylated using ATP, and that crossreacts with antibodies against the plasma cell differentiation antigen-1 (PC-1 protein) $(32,33)$ has been described. The PC1 protein is a $5^{\prime}$-phosphodiesterase/ nucleotide-pyrophosphatase (5'-PDE/ NPPase) that is structurally formed by two identical polypeptide chains bound by disulfide bridges, with molecular masses ranging from $115 \mathrm{kDa}$ to $130 \mathrm{kDa}$ depending on the species $(2,3,9,10,25$, 26, 36). Its coding sequence has been determined in mouse and human, and its protein product has a single transmembrane segment, a short intracellular N-terminal domain, and a large extracellular C- terminal domain containing the ATP catalytic site and one or two potential "E-F hand" $\mathrm{Ca}^{2+}$-binding sites $(5,9,35,36)$. Therefore, the PC-1 protein utilizes extracellular ATP as substrate (2). This enzyme belongs to a family of related mammalian ecto-enzymes whose encoding sequences have been reported $(38,39)$.

In this work, we have investigated whether the adenylylatable proteins detected in the plasma membrane from rat hepatocarcinoma AS-30D cells (6) are phosphodiesterases. Thus, we have demonstrated that the gp115 from these tumor cells is indeed a 5'-PDE/NPPase but it is distinct from the gp120-gp110 dimer (PC-1 protein) from normal rat liver plasma membrane. We also demonstrate that the tumor gp115 is an ectoenzyme that catalyzes the hydrolysis of extracellular ATP.

\section{Materials and Methods}

Reagents. $-\left[\gamma_{-}^{32} \mathrm{P}\right] \mathrm{ATP}$ and $\left[\alpha_{-}{ }^{32} \mathrm{P}\right]$ ATP were purchased from ICN, and thymidine 5'-monophosphate p-nitrophenyl ester (pNP-5'-T), ATP-agarose and AMP-agarose were obtained from Sigma. The polyclonal R244 antibody (36) against the mouse PC-1 protein, and the monoclonal 4H4 antibody (2) against the C-terminus of the human PC-1 protein were kindly provided by Dr. James W. Goding.

Preparation of plasma membrane fractions. - Plasma membrane fractions from normal rat liver and AS-30D tumor cells (31) were prepared as previously described up to the first discontinuous sucrose gradient centrifugation (29). The 5 '-nucleotidase and the ouabain-sensitive $\mathrm{Na}^{+}, \mathrm{K}^{+}$-ATPase activities were assayed as described $(12,23)$. 
Isolation of 5'-phosphodiesterase/ nucleotide-pyrophosphatases.- Plasma membranes (15-20 mg of protein) were solubilized in a medium containing 25 $\mathrm{mM}$ Hepes- $\mathrm{NaOH}(\mathrm{pH}$ 7.4), $5 \%(\mathrm{w} / \mathrm{v})$ glycerol and $1 \%$ (w/v) Triton X-100 (buffer A). The sample was centrifuged at $100,000 \mathrm{~g}_{\max }$ for $1 \mathrm{~h}$ and the supernatant was loaded on a $5 \mathrm{ml} \mathrm{ATP-agarose} \mathrm{col-}$ umn equilibrated in buffer $\mathrm{A}$. The column was washed with $100 \mathrm{ml}$ of buffer A and the 5'-PDE/NPPase was eluted from the column using a 0 to $0.5 \mathrm{mM}$ ATP gradient. Alternatively, an AMP-agarose column was utilized and the enzyme eluted using a 0 to $1 \mathrm{mM}$ AMP gradient. ATP and AMP were removed by precipitation with $83 \%(\mathrm{v} / \mathrm{v})$ acetone at $-20^{\circ} \mathrm{C}$. Alternatively, a $36 \mathrm{~h}$ dialysis at $4{ }^{\circ} \mathrm{C}$ against 1 liter with 4 changes of buffer $\mathrm{A}$ was performed. The samples were immediately used or stored at $-70{ }^{\circ} \mathrm{C}$ after lyophilization and reconstituted in buffer $\mathrm{A}$ before being used.

\section{Adenylylation and phosphorylation} assays.- The adenylylation of proteins in plasma membrane fractions were performed as described (30). The phosphorylation assays in the absence and presence of 2 units of $5^{\prime}$-nucleotidase were performed as described $(28,29,34)$. The assays using isolated proteins contained in addition $6 \%(\mathrm{w} / \mathrm{v})$ glycerol and $3 \%$ $(\mathrm{w} / \mathrm{v})$ Triton X-100. The assays in whole AS-30D tumor cells contained in addition $150 \mathrm{mM} \mathrm{NaCl}, 5 \mathrm{mM} \mathrm{KCl}, 20 \mathrm{mM}$ Tris$\mathrm{HCl}(\mathrm{pH} 7.4), 5 \mathrm{mM}$ glucose and $5 \mathrm{mM}$ sodium succinate.

In order to identify the adenylylated amino acids, the proteins were labeled with $\left[\alpha^{-32} \mathrm{P}\right] \mathrm{ATP}$ as described above, hydrolyzed with $\mathrm{HCl}$ and the released phosphoamino acid analyzed as described (13). 5'-phosphodiesterase and nucleotidepyrophosphatase assays.- The 5'-PDE activity was assayed for $1 \mathrm{~min}$ at room temperature $\left(20-22{ }^{\circ} \mathrm{C}\right)$ in $1 \mathrm{ml}$ of a medium containing $100 \mathrm{mM}$ glycine- $\mathrm{NaOH}$ (pH 9.6), $5 \mathrm{mM} \mathrm{MgCl} 2,100 \mu \mathrm{M} \mathrm{ZnCl}_{2}$ and $2 \mathrm{mM}$ pNP-5'-T. The initial rate of hydrolysis of the pNP-5'-T was followed spectrophotometrically at $400 \mathrm{~nm}$, and a millimolar extinction coefficient of 14 was used for the calculations. The NPPase activity was assayed for $15-30 \mathrm{~min}$ at 37 ${ }^{\circ} \mathrm{C}$ in $1 \mathrm{ml}$ of a medium containing 100 $\mathrm{mM}$ glycine- $\mathrm{NaOH}(\mathrm{pH}$ 9.6), $5 \mathrm{mM}$ $\mathrm{MgCl}_{2}, 100 \mu \mathrm{M} \mathrm{ZnCl}_{2}$ and $4 \mathrm{mM} \mathrm{ATP}$, in the absence and presence of 1 unit of inorganic pyrophosphatase to hydrolyze the released pyrophosphate to two phosphate molecules. The amount of inorganic phosphate formed was determined as described (24).

Immunoblots were performed with the polyclonal R244 antibody against the mouse PC-1 protein (1:400 dilution) and the monoclonal $4 \mathrm{H} 4$ antibody against the C-terminus of the human PC- 1 protein (1:200 dilution). Appropriated secondary antibodies against IgGs coupled to alkaline phosphatase (1:1,000 dilution) were used.

SDS-PAGE were performed as described (16) but using 5-20\% (w/v) polyacrylamide linear gradient gels. The gels were stained with Coomassie Brilliant Blue R-250 or silver as described (4). Protein concentration was determined as described (19).

\section{Results}

Comparative adenylylation of plasma membrane glycoproteins from normal rat liver and AS-30D tumor cells.- Figure 1 shows the adenylylation of four major proteins of $130 \mathrm{kDa}, 120 \mathrm{kDa}, 110 \mathrm{kDa}$ 


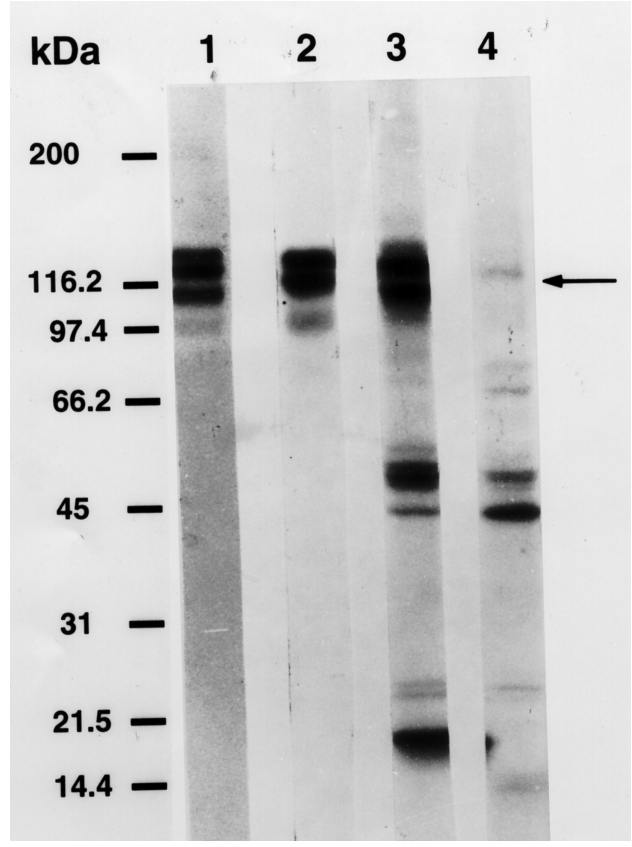

Fig. 1. Adenylylation and phosphorylation of plasma membrane proteins from normal rat liver and $A S$ $30 D$ tumor cells.

Plasma membranes from normal rat liver $(60 \mu \mathrm{g}$ of protein) (lanes 1 and 3) or AS-30D tumor cells (100 $\mu \mathrm{g}$ of protein) (lanes 2 and 4 ) were assayed with $[\alpha-$ $\left.{ }^{32} \mathrm{P}\right] \mathrm{ATP}$ (lanes 1 and 2 ) or $\left[\gamma^{32} \mathrm{P}\right] \mathrm{ATP}$ (lanes 3 and 4) and processed by SDS-PAGE and autoradiography. The arrow points to the major adenylylated and phosphorylated $115 \mathrm{kDa}$ protein from AS-30D tumor cells (lanes 2 and 4). To obtain similar labeling intensities, the exposure time of the autoradiographs of the adenylylated proteins in AS-30D tumor cells (lane 2) was 3 times longer than that of their normal rat liver counterparts (lane 1). The exposure times of the phosphorylated proteins from normal rat liver (lane 3) and AS-30D tumor cells (lane 4) were identical.

and $100 \mathrm{kDa}$ in plasma membrane from normal rat liver using $\left[\alpha_{-}{ }^{32} \mathrm{P}\right] \mathrm{ATP}$ (lane $1)$. In contrast, only three major labeled proteins of $125 \mathrm{kDa}, 115 \mathrm{kDa}$ and 105 $\mathrm{kDa}$ were detected in AS-30D tumor cells (lane 2). When the plasma membrane fractions were assayed using $\left[\gamma^{3}{ }^{32} \mathrm{P}\right] \mathrm{ATP}$ we observed several phosphorylated bands, some of which have molecular masses identical to the major adenylylated proteins detected in normal rat liver (lane 3) and AS-30D tumor cells (lane 4). In the latter case, a faint ${ }^{32} \mathrm{P}$-labeled $115 \mathrm{kDa}$ band was visible (see arrow).

We have determined that these proteins are sialic acid-rich glycoproteins, as treatment with neuraminidase significantly increases their electrophoretic mobilities. Therefore, these glycoproteins will be referred to hereafter by the letters gp followed by a number indicative of its molecular mass. The adenylylation of these glycoproteins takes place at threonine residues, and was approximately 17 -fold lower in the tumor cells than in normal rat liver (results not shown).

The gp120-gp110 dimer from normal rat liver and the gp115 from $A S-30 D$ tumor cells are distinct 5'-PDN/NPPases which form adenylylated catalytic intermediates.- We have performed experiments in order to measure the turnover of the O-adenylylated proteins from AS$30 \mathrm{D}$ tumor cells in the absence of EDTA. Figure 2 shows that the amount of $\left[{ }^{32} \mathrm{P}\right] \mathrm{AMP}$ bound to the gp125 and gp115 from AS-30D tumor cells varies from the time of the start of the reaction, reaching a maximum at $2 \mathrm{~min}$, decreasing thereafter, and attaining a plateau after $5 \mathrm{~min}$ (circles). Upon addition of an excess of nonradiolabelled ATP at $5.5 \mathrm{~min}$, a slow decrease in the $\left[{ }^{32} \mathrm{P}\right] \mathrm{AMP}$ bound to these proteins was observed (triangles). We have estimated that the half-life of the $\left[{ }^{32} \mathrm{P}\right] \mathrm{AMP}$ bound to these proteins was of approximately $2 \mathrm{~min}$ in these conditions, a value similar to that obtained for the adenylylated proteins from normal rat liver (28).

Since these adenylylatable proteins utilize ATP as substrate and covalently bind 


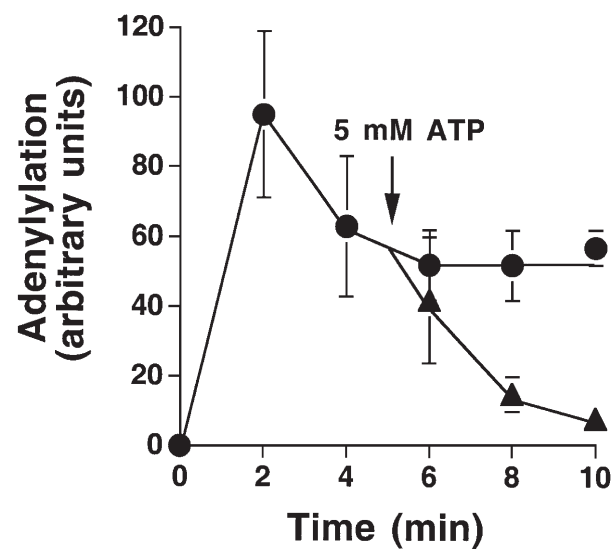

Fig. 2. Turnover of the adenylylated gp125 and gp115 from AS-30D tumor cells.

Plasma membranes from AS-30D tumor cells (600 $\mu \mathrm{g}$ of protein) were assayed with $\left[\alpha-{ }^{32} \mathrm{P}\right] \mathrm{ATP}$ as described in Materials and Methods, except that a $600 \mu$ l assay was used, EDTA was omitted and $5 \mathrm{mM}$ non-radiolabelled ATP plus $5 \mathrm{mM} \mathrm{MgCl} 2$ was added at $5.5 \mathrm{~min}$ (triangles). Controls in the absence of non-radiolabelled ATP are also presented (circles). At the indicated times, $100 \mu \mathrm{l}$ aliquots were taken and the proteins were processed by SDS-PAGE and autoradiography. The plot presents the average \pm SEM relative adenylylation of gp125 plus gp115 from three different experiments.

AMP, we have used immobilized ATP and/or AMP to attempt their isolation by ATP-affinity and/or AMP-affinity chromatographies, respectively. By using these techniques, we were able to isolate the gp120-gp110 dimer from normal rat liver (Fig. 3, panel $A$ ) and the gp115 from AS30D tumor cells (Fig. 3, panel B). As shown in Fig 3 (panel $A$ ), out of the four adenylylatable proteins present in the plasma membrane from normal rat liver (lane 1), only the gp120-gp110 dimer was isolated using either ATP-agarose (lane 2) or AMP-agarose (lane 3), as detected after adenylylation assays of the eluted material. Furthermore, we show that the eluted gp120-gp110 dimer also becomes autophosphorylated, as detected using

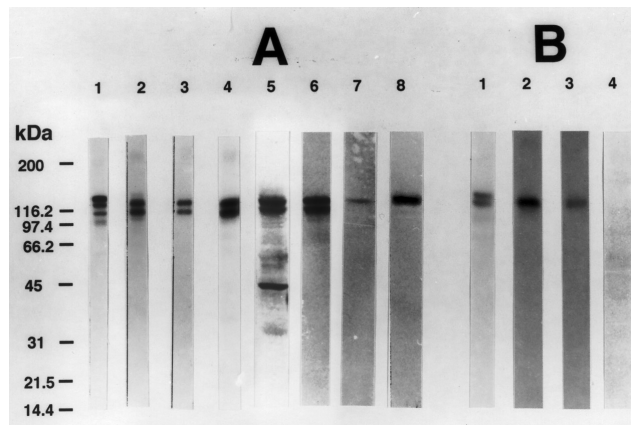

Fig. 3. Isolation and characterization of the gp120gp110 dimer from normal rat liver and the gp115 from AS-30D tumor cells.

Panel $A$ adenylylated gp130, gp120, gp110 and gp100 assayed in the plasma membranes from normal rat liver (lane 1); adenylylated gp120-gp110 dimer assayed after its isolation from an ATP-agarose column (lane 2) or an AMP-agarose column (lane 3); phosphorylated gp120-gp110 dimer assayed after its isolation from an ATP-agarose column (lane 4); immunoblots of the plasma membranes from normal rat liver (lanes 5 and 7) and the gp120-gp110 dimer isolated from the ATP-agarose column (lanes 6 and 8) probed with R244 antibody (lanes 5 and 6) or $4 \mathrm{H} 4$ antibody (lanes 7 and 8). Panel B: adenylylated gp125 and gp115 assayed in plasma membranes from AS-30D tumor cells (lane 1); adenylylated gp115 assayed after its isolation from an ATP-agarose column (lane 2); phosphorylated gp115 assayed after its isolation from an ATP-agarose column (lane 3) and plasma membranes from AS-30D tumor cells probed with $4 \mathrm{H} 4$ antibody (lane 4).

$\left[\gamma_{-}{ }^{32} \mathrm{P}\right] \mathrm{ATP}$ as substrate (lane 4$)$. In a first attempt to identify the nature of this dimer, we performed immunoblots using the R244 antibody (36), probing both the plasma membrane preparation (lane 5) and the isolated gp120-gp110 dimer (lane 6). In both cases, the gp120 and gp110 gave strong positive reactions and some additional proteins also gave a positive signal, particularly a $45 \mathrm{kDa}$ protein (lane $5)$. In contrast, when the monoclonal $4 \mathrm{H} 4$ antibody was used, only the gp120 subunit gave a positive signal when both plasma membranes (lane 7) or the isolated gp120-gp110 dimer (lane 8) were probed. 
Figure 3 (panel $B$ ) shows that out of the two major adenylylatable proteins detected in the AS-30D tumor cell plasma membranes (lane 1), only the gp115 was isolated by ATP-affinity chromatography (lane 2), as shown after its adenylylation assay. Similarly, this protein was able to undergo autophosphorylation, detected using $[\gamma-$ $\left.{ }^{32} \mathrm{P}\right] \mathrm{ATP}$ as substrate (lane 3). Unlike the gp120-gp110 dimer from normal rat liver, none of the AS-30D tumor cell plasma membrane proteins were recognized by the 4H4 antibody (lane 4).

We have found that the gp120-gp110 dimer isolated from normal rat liver and the gp115 isolated from AS-30D tumor cells exhibited both 5'-PDE and NPPase activities when assayed under alkaline conditions ( $\mathrm{pH}$ 9.6) with $\mathrm{pNP}-5$ '-T and ATP, respectively. Both enzymatic activities displayed typical Michaelis-Menten kinetic behavior and exhibited a clear dependence on $\mathrm{Zn}^{2+}$ (results not shown). The gp120-gp110 dimer from normal rat liver shows $\mathrm{K}_{\mathrm{m}}$ values for $\mathrm{pNP}-5$ '-T and ATP of $220 \mu \mathrm{M}$ and $50 \mu \mathrm{M}$, respectively. In contrast, the gp115 from AS-30D tumor cells shows $\mathrm{K}^{\prime} \mathrm{m}$ values for $\mathrm{pNP}-5^{\prime}$ $\mathrm{T}$ and ATP of $97 \mu \mathrm{M}$ and $400 \mu \mathrm{M}$, respectively. A high 5'-PDE activity was also detected in normal rat liver plasma membranes at alkaline $\mathrm{pH}$. As expected, the AS-30D tumor cell plasma membranes exhibited a 5'-PDE activity that was 6 to 16 -fold lower than that from normal rat liver plasma membranes (6).

The gp125 and the gp115 from AS-30D tumor cells are ecto-enzymes.- To study whether the gp115 from AS-30D tumor cells, which also exhibits 5'-PDE/NPPase activity, is also an ecto-enzyme, we performed adenylylation and phosphorylation assays in intact cells grown in culture using exogenously added $\left[\alpha^{-32}\right.$ P]ATP and $\left[\gamma^{32} \mathrm{P}\right]$ ATP, respectively. Figure 4 (panels $A$ and $B$ ) shows that the gp115 becomes adenylylated when assayed with exogenously added $\left[\alpha_{-}{ }^{32} \mathrm{P}\right]$ ATP to very similar intensities both in the absence (lanes 1) or in the presence (lanes 2 to 4 ) of increasing concentrations of the detergent digitonin (panel $A$ ) or the ATP-permeabilizing agent alamethicin (panel B). Moreover, the gp125 also became labeled in these conditions. Likewise, when phosphorylation assays were performed using exogenously added $\left[\gamma^{3}{ }^{32} \mathrm{P}\right]$ ATP (Fig. 4 , panels $C$ and $D)$, the gp115 was also labeled in the absence (lanes 1) and in the presence (lanes 2 to 4 ) of increasing concentrations of the detergents Triton X-100 (panel C) or digitonin (panel $D$ ). Interestingly, another protein of approximately $40 \mathrm{kDa}$ was also strongly phosphorylated with

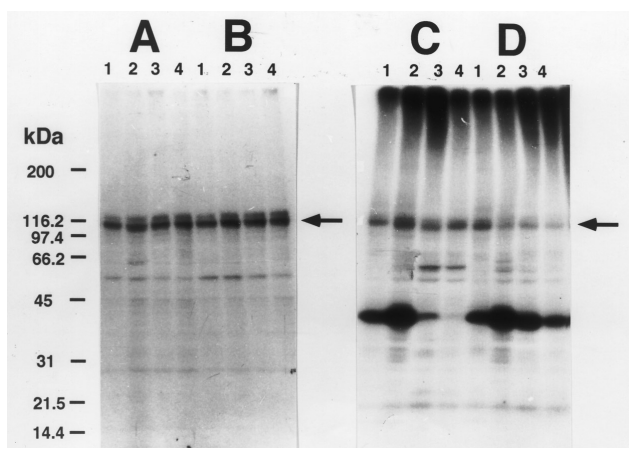

Fig. 4. Adenylylation and/or phosphorylation of the gp125 and gp115 in whole AS-30D tumor cells using extracellular ATP.

AS-30D tumor cells grown in culture were assayed for adenylylation using $\left[\alpha-{ }^{32} \mathrm{P}\right] \mathrm{ATP}$ (panels $A$ and $B$ ) or for phosphorylation using [ $\gamma^{-32}$ P]ATP (panels $C$ and $D)$ in the absence of any permeabilizing agent (lanes 1), or in the presence of digitonin (panels $A$ and $D$ ), alamethicin (panel $B$ ), or Triton X-100 (panel $C$ ) at the following concentrations: $0.01 \%$ (w/v) (lanes 2), $0.05 \%(\mathrm{w} / \mathrm{v})$ (lanes 3), and $0.1 \%$ $(\mathrm{w} / \mathrm{v})$ (lanes 4) are presented. Thereafter, the samples were processed by SDS-PAGE and the radiolabelled proteins were visualized by autoradiography. The arrow points to the gp 115 . 
extracellular ATP in the absence of any permeabilizing agent. This phosphorylation decreased upon addition of permeabilizing agents, particularly when Triton $\mathrm{X}-100$ was used. In contrast, the gp125 was not significantly phosphorylated under these conditions.

\section{Discussion}

The plasma membrane of mammalian cells contains a series of ecto-enzymes that are involved in the degradation of extracellular nucleoside 5'-triphosphates $(38,39)$. In this study, we show differences in the number and apparent molecular masses between two sets of adenylylatable proteins present in normal rat liver and AS-30D tumor cells, suggesting that they represent distinct molecular species. Moreover, the level of adenylylation of the glycoproteins from AS-30D tumor cells are far lower than those from normal rat liver. This suggests a differential expression of these glycoproteins in the tumor cells as compared to normal rat liver. We also demonstrate that the gp120gp110 dimer from normal rat liver and the gp115 from AS-30D tumor cells are 5'$\mathrm{PDE} / \mathrm{NPP}$ ases. It is interesting to mention that the activity of another typical ecto-enzyme such as the $5^{\prime}$-nucleotidase is also significantly lower in AS-30D tumor cells than in normal rat liver plasma membranes (6). It should be emphasized that the sequential action of 5'-PDE/NPPases and 5'-nucleotidases transforms extracellular ATP into adenosine, and that both ATP and adenosine are agonists of great physiological relevance $(8,11,18,38,39)$.

The attempts to isolate some of these adenylylatable glycoproteins from normal rat liver and AS-30D tumor cells by ATPand/or AMP-affinity chromatographies were successful, as also shown by other authors using different biological sources $(20,37)$. On the other hand, neither the gp130 and gp100 from normal rat liver, or the gp125 and gp105 from tumor cells, were isolated by these chromatographic methods.

Although the 5'-PDE/NPPases isolated from normal rat liver and AS-30D tumor cells exhibit several functional enzymatic analogies, they bear significant differences so as to be considered two related but distinct enzymes. The most striking difference is the fact that the gp120 and the gp110 from normal rat liver form dimers bound by disulfide bridges, as demonstrated in their membranebound form (28) and in their solubilized and isolated form, whereas no traces of dimeric structures of the gp115 were found when plasma membranes from AS30D tumor cells were processed by SDSPAGE under non-reducing conditions (results not shown). Nevertheless, it is important to mention that the bands corresponding to the plasma membranebound gp125 and gp115 from AS-30D tumor cells disappear when processed by SDS-PAGE in the absence of $\beta$-mercaptoethanol, which leaves open the possibility of formation of higher-order oligomers between these glycoproteins. Other relevant differences between the normal rat liver gp120-gp110 dimer and the tumor gp115 supporting their consideration as two distinct entities are their dissimilar 5'$\mathrm{PDE}$ to NPPase activity ratios and $\mathrm{K}^{\prime} \mathrm{m}$ values for $\mathrm{pNP}-5^{\prime}-\mathrm{T}$ and ATP.

As documented in the Results section, the gp120-gp110 dimer from normal rat liver was identified as the rat $\mathrm{PC}-1$ protein by immunoblot analysis using two different antibodies. Even so, the gp110 subunit should lack the epitope present at the gp120 C-terminus recognized by one of the antibodies used. The PC-1 protein 
from different origins has been described as a homodimer $(5,9,10,21)$. Therefore, the presence of two clearly distinct subunits forming the rat liver PC-1 protein is puzzling. Two interpretations could account for these results: Either the gp110 derives from alternative splicing of the gp120 transcript, or the gp110 is a proteolytic product of the gp120. The first option is supported by the fact that alternative splicing has been suggested to occur for the hnRNA of the human PC-1 protein (14).

We have demonstrated that the gp115 is a distinct ecto-5'-PDE/NPPase present in AS-30D tumor cells. In contrast, the classical PC-1 protein from normal rat liver (gp120-gp110 dimer) is absent from the plasma membrane of this tumor cell line. Other tumor cells are known to express similar enzymes. Thus, autotaxin/phosphodiesterase- $1 \alpha$ is a related ecto-5'PDE/NPPase that is present in human neuroblastoma cells, and is involved in the stimulation of cell motility $(15,39)$. It has been shown that overexpression of the PC-1 protein inhibits the autophosphorylation of the insulin receptor tyrosine kinase, contributing to the pathogenesis of non-insulin-dependent diabetes mellitus (20), and to the insulin-resistance observed in some breast cancer cell lines (1). Therefore, the absence of the PC-1 protein in AS-30D tumor cells suggests that its regulatory role on the insulin receptor could also be absent. Moreover, both the PC-1 protein (33) and a related protein, termed phosphodiesterase$1 \beta / \mathrm{B} 10 / \mathrm{gp} 130^{\mathrm{RB} 13-6}(7,38,39)$, appear to be expressed during cell differentiation. Consequently, its absence or down-regulation in highly undifferentiated tumor cells with a high proliferation rate, such as the hepatocarcinoma cells used in this study, is an agreeable observation. This suggests that these ecto-5'-PDE/NPPases could play an important role in metabolic control and in differentiation and/or proliferation processes.

\section{Acknowledgements}

This work was financed by grants to AV from the Comisión Interministerial de Ciencia y Tecnología (SAF99-0052), the Consejería de Educación y Cultura de la Comunidad de Madrid (08.5/0019/1997), and the Agencia Española de Cooperación Internacional (99CN0011). RMG-N was supported by a predoctoral fellowship from the Ministerio de Educación y Cultura. We thank Dr. Marco G. Paggi from the Regina Elena Cancer Institute at Rome, Italy, for his donation of the AS-30D tumor cell line, and Dr. James W. Goding from the Monash Medical School, Victoria, Australia, for his kind gift of antibodies against the PC-1 protein. We gratefully acknowledge Dr. Miguel Quintanilla for critically reading the manuscript and useful suggestions.

R. M. GARCÍA-NIETO, E. SAN JOSÉ, J. MARTÍN-NIETO y A. VILLALOBO. Nueva ecto-5'-fosfodiesterasa/nucleótido-pirofosfatasa asociada a la membrana plasmática de células AS-30D de hepatocarcinoma de rata. J. Physiol. Biochem., 57 (1), 31-40, 2001.

Se identifican en fracciones de membranas plasmáticas aisladas de células ascíticas AS30D de hepatocarcinoma de rata, tres glicoproteínas de $125 \mathrm{kDa}, 115 \mathrm{kDa}$ y $105 \mathrm{kDa}$ (gp125, gp115 y gp 105) que son adenililadas utilizando ATP como sustrato. Esta adenililación es más intensa en presencia de EDTA. La gp115 también se fosforila utilizando ATP como sustrato. La adenililación de estas glicoproteínas tumorales es mucho más débil que la adenililación de un grupo análogo de glicoproteínas (gp130, dímero gp120-gp110 y gp100) presentes en membranas plasmáticas aisladas de hígado normal de rata. Las glicoproteínas de las células tumorales y de hígado normal se $\mathrm{O}$ adenililan reversiblemente en residuos de treonina. La gp115 tumoral y el dímero gp120- 
gp110 de hígado normal se aíslan mediante cromatografías de afinidad usando ATP y/o AMP inmovilizado. El dímero gp120-gp110 de hígado normal se identifica como el antígeno de diferenciación-1 de células plasmáticas (proteína PC-1), una ecto-5'-fosfodiesterasa/nucleótido-pirofosfatasa (5'-FDE/NPFasa). La gp115 de células tumorales también presenta actividades 5'-FDE y NPFasa estimuladas por $\mathrm{Zn}^{2+}$ en condiciones alcalinas, aunque parece ser una proteína diferente a la proteína PC-1. Se ha determinado también que la gp115 es una ecto-enzima que cataliza la hidrólisis de ATP extracelular, ya que resulta adenililada y fosforilada en células intactas añadiendo al medio $\left[\alpha-{ }^{32} \mathrm{P}\right]$ ATP o $\left[\gamma^{32} \mathrm{P}\right] \mathrm{ATP}$, respectivamente, en ausencia de agentes permeabilizantes.

Palabras clave: Adenililación, Células AS-30D, Ecto-5'-fosfodiesterasa/nucleótido-pirofosfatasa, Hepatocarcinoma.

\section{References}

1. Belfiore, A., Costantino, A., Frasca, F., Pandini, G., Mineo, R., Vigneri, P., Maddux, B., Goldfine, I. D. and Vigneri, R. (1996): Mol. Endocrinol., 10, 1318-1326.

2. Belli, S. I., Sali, A. and Goding, J. W. (1994): Biochem. J., 304, 75-80.

3. Belli, S. I. and Goding, J. W. (1994): Eur. J. Biochem., 226, 433-443.

4. Blum, H., Beier, H. and Gross, H. J. (1987): Electrophoresis, 8, 93-99.

5. Buckley, M. F., Loveland, K. A., McKinstry, W. J., Garson, O. M. and Goding, J. W. (1990): J. Biol. Chem., 265, 15789-15794.

6. Church, J. G., Ghosh, S., Roufogalis, B. D. and Villalobo, A. (1988): Biochem. Cell Biol., 66, 112.

7. Deissler, H., Lottspeich, F. and Rajewsky, M. F. (1995): J. Biol. Chem., 270, 9849-9855.

8. El-Moatassim, C., Dornard, J. and Mani, J.-C. (1992): Biochim. Biophys. Acta, 1134, 31-45.

9. Funakoshi, I., Kato, H., Horie, K., Yano, T., Hori, Y., Kobayashi, H., Inoue, T., Suzuki, H., Fukui, S., Tsukahara, M., Kajii, T. and Yamashina, I. (1992): Arch. Biochem. Biophys., 295, 180-187.

10. Goding, J. W. and Shen, F.-W. (1982): J. Immunol., 129, 2636-2640.

11. Gordon, J. L. (1986): Biochem. J., 233, 309-319.
12. Heppel, L. A. and Hilmoe, R. J. (1955): Methods Enzymol., 2, 546-549.

13. Hunter, T. and Sefton, B. M. (1980): Proc. Natl. Acad. Sci. USA, 77, 1311-1315.

14. Jin-Hua, P., Goding, J. W., Nakamura, H. and Sano, K. (1997): Genomics, 45, 412-415.

15. Kawagoe, H., Stracke, M. L., Nakamura, H. and Sano, K. (1997): Cancer Res., 57, 2516-2521.

16. Laemmli, U. K. (1970): Nature, 227, 680-685.

17. Landt, M. and Butler, L. G. (1978): Biochemistry, 17, 4130-4135.

18. Linden, J., Tuckee, A. L. and Lynch, K. R. (1991): Trends Pharmacol. Sci., 12, 326-328.

19. Lowry, O. H., Rosebrough, N. J., Farr, A. L. and Randall, R. J. (1951): J. Biol. Chem., 193, 265-275.

20. Maddux, B. A., Sbraccia, P., Kumakura, S., Sasson, S., Youngren, J., Fisher, A., Spencer, S., Grupe, A., Henzel, W., Stewart, T. A., Reaven, G. A. and Goldfine, I. D. (1995): Nature, 373, 448-451.

21. Oda, Y., Kuo, M., Huang, S. S. and Huang, J. S. (1991): J. Biol. Chem., 266, 16791-16795.

22. Oda, Y., Kuo, M., Huang, S. S. and Huang, J. S. (1994): J. Biol. Chem., 268, 27318-27326.

23. Post, R. L. and Sen, A. K. (1967): Methods Enzymol., 10, 762-768.

24. Raess, B. U. and Vincenzi, F. F. (1980): J. Pharmacol. Methods, 4, 273-283.

25. Rebbe, N. F., Tong, B. D., Finley, E. M. and Hickman, S. (1991): Proc. Natl. Acad. Sci. USA, 88, 5192-5196.

26. Rebbe, N. F., Tong, B. D., Finley, E. M. and Hickman, S. (1993): Mol. Immunol., 30, 87-93.

27. Rugevics, C.-U. and Witzel, H. (1982): Biochem. Biophys. Res. Commun., 106, 72-78.

28. San José, E., Benguría, A. and Villalobo, A. (1990): J. Biol. Chem., 265, 20653-20661.

29. San José, E., Benguría, A., Gabius, H.-J. and Villalobo, A. (1993): In "Lectins and Glycobiology” (H.-J. Gabius and S. Gabius, eds.). SpringerVerlag, Heidelberg/New York, pp. 329-355.

30. San José, E., Villalobo, E., Gabius, H.-J. and Villalobo, A. (1993): Biol. Chem. Hoppe-Seyler, 374, 133-141.

31. Smith, D. F., Walborg, E. F., Jr. and Chang, J. P. (1970): Cancer Res., 30, 2306-2309.

32. Stefan, C., Stalmans, W. and Bollen, M. (1996): Eur. J. Biochem., 241, 338-342.

33. Takahashi, T., Old, L. J. and Boyse, E. A. (1970): J. Exp. Med., 131, 1325-1341.

34. Uriarte, M., Stalmans, W., Hickman, S. and Bollen, M. (1993): Biochem. J., 293, 93-100.

35. van Driel, I. R. and Goding, J. W. (1987): J. Biol. Chem., 262, 4882-4887. 
36. Van Driel, I. R., Goding, J. W. and Koch, N. (1985): J. Immunol., 134, 3987-3993.

37. Yano, T., Funakoshi, I. and Yamshina, I. (1985): J. Biochem., 98, 1097-1107.
38. Zimmermann, H. (1999): Trends Pharmacol. Sci., 20, 231-236.

39. Zimmermann, H. and Braun, N. (1999): Prog. Brain Res., 120, 371-385. 